\title{
Correction to: Human-Al collaborative decision-making as an organization design problem
}

\author{
Phanish Puranam ${ }^{1}$
}

Published online: 25 March 2021

(c) The Author(s) 2021

\section{Correction to: J Org Des (2021) https://doi.org/10.1007/s41469-021-00095-2}

The article Human-AI collaborative decision-making as an organization design problem, written by Phanish Puranam (1), was originally published electronically on the publisher's internet portal on 4 Feb 2021 without open access. This is now corrected and the article is forthwith distributed under a Creative Commons Attribution 4.0 International License, which permits use, sharing, adaptation, distribution and reproduction in any medium or format, as long as you give appropriate credit to the original author(s) and the source, provide a link to the Creative Commons licence, and indicate if changes were made. The images or other third party material in this article are included in the article's Creative Commons licence, unless indicated otherwise in a credit line to the material. If material is not included in the article's Creative Commons licence and your intended use is not permitted by statutory regulation or exceeds the permitted use, you will need to obtain permission directly from the copyright holder. To view a copy of this licence, visit http://creativecommons.org/licenses/by/4.0.

The original article can be found online at https://doi.org/10.1007/ s41469-021-00095-2.

Phanish Puranam

Phanish.puranam@insead.edu

1 INSEAD, 1 Ayer Rajah Avenue, Singapore, Singapore
Open Access This article is licensed under a Creative Commons Attribution 4.0 International License, which permits use, sharing, adaptation, distribution and reproduction in any medium or format, as long as you give appropriate credit to the original author(s) and the source, provide a link to the Creative Commons licence, and indicate if changes were made. The images or other third party material in this article are included in the article's Creative Commons licence, unless indicated otherwise in a credit line to the material. If material is not included in the article's Creative Commons licence and your intended use is not permitted by statutory regulation or exceeds the permitted use, you will need to obtain permission directly from the copyright holder. To view a copy of this licence, visit http://creativecommons.org/licenses/by/4.0/.

\section{Reference}

Puranam P (2021) Human-AI collaborative decision-making as an organization design problem. J Org Des. https://doi.org/10.1007/ s41469-021-00095-2

Publisher's Note Springer Nature remains neutral with regard to jurisdictional claims in published maps and institutional affiliations. 